\title{
Mortality experience of glass fibre workers
}

\author{
H S SHANNON, M HAYES, J A JULIAN, AND D C F MUIR \\ From the Occupational Health Program, McMaster University Health Sciences Centre, Hamilton, Ontario \\ L8N 3Z5, Canada
}

\begin{abstract}
A historical prospective mortality study was conducted at an insulating wool plant in Ontario, Canada, on 2576 men who had worked for at least 90 days and were employed between 1955 and 1977. Eighty eight deaths were found in the $97.2 \%$ of men traced. Mortality was compared by the person-years method with that of the Ontario population. Measurements taken since 1977 show very low fibre concentrations. The overall standardised mortality ratio (SMR) was $78 \%$, significantly below 100 . Among plant only employees, seven deaths were attributed to lung cancer compared with 4.22 expected, a non-significant excess (SMR $=166 ; 95 \%$ confidence limits 67 to 342). No confirmed cases of mesothelioma were observed and no other disease was significantly increased in plant workers.
\end{abstract}

Glass fibre has many uses but is also under suspicion as a carcinogen since animal implantation work strongly implies that the dimensions of fibres are more important than their composition with respect to potential carcinogenicity. ${ }^{1}$ Indeed animal studies have found that implantation of glass fibres can produce tumours in rats, ${ }^{2}$ but studies of exposed individuals have failed to detect such effects, ${ }^{34}$ although Bayliss found an excess of non-malignant respiratory disease. ${ }^{5}$

The present paper reports a historical prospective mortality study of workers engaged in the manufacture of glass fibre. Of especial interest were lung and gastrointestinal cancers, particularly mesotheliomas. Attention was also to be given to non-malignant respiratory disease.

\section{Methods and material}

\section{SITE OF STUDY}

An insulating wool plant in Sarnia, Ontario, Canada, was the location of the study. It opened in 1948 with about 200 hourly rated employees and currently has about 500 . Initially, a steam blown fibre was produced but a change was made to centrifugally formed fibres in 1961. A small flame attenuation process occupied a separate area from the mid-1950s until 1974.

STUDY POPULATION

It was originally planned to include all workers who

Received 15 November 1982

Accepted 10 January 1983 had been employed for a total of 30 days at any time between the opening of the plant in 1948 and the end of 1977. It was discovered, however, that the main source of records of employees who left before 1969 was incomplete. By using income tax records of all employees who worked between 1960 and 1969 together with union records, group insurance rolls, and seniority lists from 1955 to 1962 it was possible to generate a complete list of all the men who had worked at least 90 days and were employed at any time from 1955 onwards. Although records of other employees who left before then were located, it was impossible to be sure that the list was complete and would not omit a group among whom the number of deaths might be disproportionately high. In addition, it was noted that few, if any, women had genuine exposure to glass fibre.

It was thus decided that the study group would comprise only those men who had worked at the plant between 1955 and 1977 and who had had at least 90 days' total employment; 2576 such men were studied.

PERSONAL DATA AND WORK HISTORIES

Wherever possible detailed work histories were compiled for the study subjects. Not all of these were available, however, although individuals could be divided into three groups: those who worked in the plant only, those who worked in the office area only, and those whose job entailed a combination of plant and office work ("mixed exposure").

In addition, other personal information-such as full name, date of birth, and last known addresswere extracted from the records. These data were to 35 
assist in tracing those who had left the company. The data were transcribed into machine readable form by study team personnel, using mainly a microfiche copy of the original documents.

\section{MORTALITY ASCERTAINMENT}

Vital status was unknown for most of the population and various methods were used to trace these men. Two students were hired to make contact with subjects who might have remained in the area or with family or friends who could provide information. Driver licence bureaus in Ontario and other Canadian provinces consented to a search of their data bases. Statistics Canada's Vital Statistics and Disease Registry found that some subjects had died and provided dates and official causes of death for these men as well as for those found to be dead through other means. Other follow up methods included the use of street directories and telephone books of the local area, current plant employees, driver licensing records, and the United States Department of Immigration and Naturalization. Sources of tracing were recorded and documentation retained.

\section{ANALYSIS}

The primary analysis adopted the person-years approach described by Case and Lea, ${ }^{6}$ using a computer program written by one of us (JJ). Age and calendar specific death rates were computed and compared with those of the Ontario male population. Indirect adjustment was made and SMRs calculated.

Statistical tests of significance were applied by treating the observed number of deaths as a Poisson variate with a mean equal to the expected number of deaths. When the expected number was greater than three, the approximation to the normal distribution was adopted. The statistical tests were two-sided; an $\alpha$ of 0.05 was used as the primary level of significance. Because the numbers are small, $95 \%$ confidence intervals have been calculated for some SMRs to indicate the range of possible values.

ENVIRONMENTAL DATA

Historical exposure data were not available for the period of study. Samples taken in 1978 and 1979 suggest that optical microscopy counts are rarely over 0.2 fibres $/ \mathrm{ml}$ and the mean levels in most areas were below $0 \cdot 1$ fibres $/ \mathrm{ml}$.

\section{Results}

Table 1 shows the distribution of person-years by age and calendar period. It should be noted that some men were employed before 1955 but were only under observation from 1955 onwards. Only 502 men contributed person-years beyond 20 years from their first exposure (13 of these were office workers who would have had very little exposure to fibrous glass dust). The number of men exposed 15 or more years was 303 , eight of whom were office employees.

All but 74 men were traced, giving a follow up rate of $97.2 \%$. Seventeen of those not found were believed to have emigrated to the United States. Of the remainder, a search of the National Mortality Data Base at Statistics Canada did not yield a death record. Since it is very probable that if any had died in Canada a death certificate would have been located, the effective follow up can be considered greater than $97.2 \%$.

Eighty eight men were found to have died and death certificates were located for all but one of them. Additional data suggested that this death was due to ischaemic heart disease and this cause has been used in the analysis.

The expected number of deaths was 113.3 giving a significantly low SMR of $78 \%\left(\chi_{1}^{2}=5 \cdot 65, p=\right.$ 0.02 ). While at least a part of the deficit might have been expected in an occupational population, when the analysis was restricted to observation at least 10 years after first employment the SMR was still low-56 deaths observed $v 75.54$ expected, SMR $=$ 74 . One would have expected the healthy worker effect to have largely attenuated.

Mortality was examined by dividing the population into the three groups described above (plant only, office only, and mixed exposure). Table 2 shows the observed and expected deaths by ICD chapter headings for those categories with at least three deaths. Circulatory diseases were fewer than expected in plant only employees but slightly more numerous in men with mixed exposure. Neither difference was statistically significant. Mortality from

Table 1 Person-years at risk by age and calendar period

\begin{tabular}{|c|c|c|c|c|c|c|c|c|}
\hline Calendar period & 25 & $25-$ & $35-$ & Age 45- & $55-$ & $65-$ & $\geqslant 75$ & Total \\
\hline $\begin{array}{l}1955-9 \\
1960-4 \\
1965-9 \\
1970-4 \\
1975-7 \\
\text { Total }\end{array}$ & $\begin{array}{r}433 \\
534 \\
1670 \\
2066 \\
1650 \\
6353\end{array}$ & $\begin{array}{l}1001 \\
1177 \\
1512 \\
2840 \\
2561 \\
9091\end{array}$ & $\begin{array}{r}636 \\
1011 \\
1447 \\
1551 \\
1048 \\
5693\end{array}$ & $\begin{array}{r}254 \\
437 \\
770 \\
1171 \\
882 \\
3514\end{array}$ & $\begin{array}{r}94 \\
181 \\
257 \\
429 \\
407 \\
1368\end{array}$ & $\begin{array}{r}3 \\
19 \\
88 \\
127 \\
103 \\
340\end{array}$ & $\begin{array}{r}0 \\
2 \\
5 \\
18 \\
33 \\
58\end{array}$ & $\begin{array}{r}2421 \\
3361 \\
5749 \\
8202 \\
6684 \\
26417\end{array}$ \\
\hline
\end{tabular}


Table 2 Mortality by major cause group for plant, office, and mixed exposure groups

\begin{tabular}{|c|c|c|c|c|c|c|c|c|c|}
\hline \multirow[t]{2}{*}{ Cause group } & \multicolumn{3}{|c|}{ Plant only } & \multicolumn{3}{|c|}{ Office only } & \multicolumn{3}{|c|}{ Mixed } \\
\hline & $O$ & $E$ & $S M R$ & $\bar{O}$ & $E$ & $S M R$ & $\bar{O}$ & $E$ & $S M R$ \\
\hline $\begin{array}{l}\text { Circulatory diseases } \\
\text { All cancers } \\
\text { Accidents, violence etc } \\
\text { Respiratory disease } \\
\text { Digestive system disorders } \\
\text { Other causes } \\
\text { Total }\end{array}$ & $\begin{array}{r}30 \\
17 \\
13 \\
4 \\
3 \\
5 \\
72\end{array}$ & $\begin{array}{r}40 \cdot 74 \\
16 \cdot 56 \\
22 \cdot 51 \\
4 \cdot 38 \\
4 \cdot 00 \\
6 \cdot 78 \\
94 \cdot 97\end{array}$ & $\begin{array}{r}74 \\
103 \\
58 \\
91 \\
76 \\
74 \\
76\end{array}$ & $\begin{array}{l}3 \\
2 \\
0 \\
0 \\
0 \\
1 \\
6\end{array}$ & $\begin{array}{l}3 \cdot 70 \\
1 \cdot 53 \\
2 \cdot 50 \\
0 \cdot 42 \\
0 \cdot 40 \\
0 \cdot 70 \\
9 \cdot 25\end{array}$ & $\begin{array}{r}81 \\
131 \\
0 \\
0 \\
0 \\
143 \\
65\end{array}$ & $\begin{array}{r}7 \\
1 \\
2 \\
0 \\
0 \\
0 \\
10\end{array}$ & $\begin{array}{l}3 \cdot 83 \\
1 \cdot 56 \\
1 \cdot 39 \\
0 \cdot 36 \\
0 \cdot 39 \\
0 \cdot 57 \\
8 \cdot 10\end{array}$ & $\begin{array}{r}183 \\
64 \\
144 \\
0 \\
0 \\
0 \\
123\end{array}$ \\
\hline
\end{tabular}

O = Observed number of deaths.

$\mathrm{E} \quad=$ Expected number of deaths.

$\mathrm{SMR}=$ Standardised mortality ratio $=\frac{\mathrm{O}}{\mathrm{E}} \times 100$.

all cancers was almost identical with that expected (20 observed $v 19.65$ expected) with little variation by exposure. Deaths due to accidents and other violent causes were low, significantly so for plant only workers $\left(\chi_{1}^{2}=4.02, p=0.04\right)$. Non-malignant respiratory diseases accounted for four deaths. All these occurred in plant workers among whom the SMR was 91. The remaining causes of death showed no excess.

Mortality from more specific causes is shown in table 3. Ischaemic heart disease was low in plant workers and high in mixed exposure employees, although neither difference from expected was statistically significant $\left(\chi_{1}^{2}=3.29\right.$ and $3.44, p=$ 0.07 and 0.06 respectively). Seven deaths from lung cancer were observed in plant only employees against 4.22 expected. The SMR of 166 , though, was not statistically significant $\left(\chi_{1}^{2}=1 \cdot 83, \mathrm{p}=\right.$ $0 \cdot 18$ ). Among office workers the SMR was 560 but with only two deaths the excess was not statistically significant $(\mathrm{p}=0 \cdot 10)$.

The $95 \%$ confidence interval on the lung cancer SMR for plant only workers was 67 to 342 . Because of the width of this interval the data were considered by duration of exposure and by time since first exposure. An increase in the SMR with increasing levels of these variables would suggest a genuine relationship. Table 4 shows these data. While the numbers of deaths become even fewer, the data do not support the hypothesis of a link between occupa- tional exposure to glass fibre and increased lung cancer mortality.

Permission was granted by the Ontario Registrar General's Office to contact the hospitals in which the deaths from cancer had occurred. All but two such deaths occurred in Ontario. The records showed one man with stomach cancer in whom the clinical history suggested the possibility of mesothelioma. He started working with the company in 1948 at age 38, left in 1966, and died in 1976. Tissue samples were sent to the Canadian Tumour Reference Centre to confirm or refute this diagnosis. Of three pathologists who reviewed the material, two believed it to show a sarcoma, while the third thought that mesothelioma was a distinct possibility. On balance, therefore, it was concluded that a diagnosis of mesothelioma could not be confirmed.

Cerebrovascular deaths and those due to cancers of the digestive organs and peritoneum were roughly equal to their expected numbers. Three deaths were ascribed to "bronchitis, emphysema, and asthma," although since these three causes accounted for one death each, further comment seems unwarranted. Among plant only workers the three cancers of the genitourinary organs gave a SMR of 161. Three different sites were affected, however: genital organs, kidney, and bladder. Lymphatic and haematopoietic malignancies had a SMR (in plant workers) of $92(.2 \cdot 0$ observed $v 2 \cdot 18$ expected).

Table 3 Mortality from selected causes for plant, office, and mixed exposure groups

\begin{tabular}{|c|c|c|c|c|c|c|c|c|c|}
\hline \multirow[t]{2}{*}{ Specific cause } & \multicolumn{3}{|c|}{ Plant only } & \multicolumn{3}{|c|}{ Office only } & \multicolumn{3}{|c|}{ Mixed exposure } \\
\hline & $O$ & $E$ & $S M R$ & $O$ & $E$ & $S M R$ & $O$ & $E$ & $S M R$ \\
\hline $\begin{array}{l}\text { Ischaemic heart disease } \\
\text { Lung cancer } \\
\text { Cerebrovascular } \\
\text { Cancer of digestive organs and peritoneum } \\
\text { Bronchitis, emphysema and asthma } \\
\text { Cancer of genitourinary organs } \\
\text { Lymphatic and haematopoietic malignancies }\end{array}$ & $\begin{array}{r}20 \\
7 \\
5 \\
5 \\
3 \\
3 \\
2\end{array}$ & $\begin{array}{r}29 \cdot 92 \\
4 \cdot 22 \\
5 \cdot 18 \\
5 \cdot 34 \\
1 \cdot 62 \\
1 \cdot 86 \\
2 \cdot 18\end{array}$ & $\begin{array}{r}67 \\
166 \\
97 \\
94 \\
186 \\
161 \\
92\end{array}$ & $\begin{array}{l}3 \\
2 \\
0 \\
0 \\
0 \\
0 \\
0\end{array}$ & $\begin{array}{l}2 \cdot 67 \\
0.36 \\
0.49 \\
0.47 \\
0.14 \\
0.18 \\
0.23\end{array}$ & $\begin{array}{r}112 \\
560 \\
0 \\
0 \\
0 \\
0 \\
0\end{array}$ & $\begin{array}{l}7 \\
0 \\
0 \\
0 \\
0 \\
1 \\
0\end{array}$ & $\begin{array}{l}2.94 \\
0.44 \\
0.41 \\
0.51 \\
0.15 \\
0.14 \\
0.18\end{array}$ & $\begin{array}{r}238 \\
0 \\
0 \\
0 \\
0 \\
694 \\
0\end{array}$ \\
\hline
\end{tabular}


Table 4 Lung cancer mortality by duration of exposure and by time since first exposure - plant only workers

\begin{tabular}{|c|c|c|c|c|c|c|}
\hline \multirow[t]{2}{*}{$\begin{array}{l}\text { Time since first } \\
\text { exposure (years) }\end{array}$} & \multicolumn{6}{|c|}{$\underset{<5}{\text { Duration of exposure (years) }}>5$} \\
\hline & $O$ & $E$ & $S M R$ & $O$ & $E$ & $S M R$ \\
\hline $\begin{array}{l}<10 \\
\geqslant 10\end{array}$ & $\begin{array}{l}1 \\
1\end{array}$ & $\begin{array}{l}0.31 \\
0.45\end{array}$ & $\begin{array}{l}321 \\
223\end{array}$ & $\begin{array}{l}0 \\
5\end{array}$ & $\begin{array}{l}0.28 \\
3 \cdot 18\end{array}$ & $\begin{array}{r}0 \\
157\end{array}$ \\
\hline
\end{tabular}

\section{Discussion}

A major focus of the study was on lung cancer. As noted, the $95 \%$ confidence interval on the SMR for that cause for plant workers was very wide (67 to 342 ). Indeed, the power of the study to detect (at an $\alpha$ of 0.05 ) a true twofold risk of lung cancer mortality was only $42 \%$. The more detailed breakdown (table 4), however, did not suggest a genuine relationship. Examination of hospital records found a possible case of mesothelioma, but further pathological examination could not confirm this.

Among other diseases of interest, none showed a significant excess. Indeed, both cancers of the digestive organs and peritoneum and non-malignant respiratory disease were slightly fewer than expected.

No other disease produced a statistically significant SMR, except for accidents and violence. The reason for the shortfall is not clear. The age standardised male death rate from these causes in Lambton county (in which the plant is located) from 1966 to 1976 was 103.6 compared with 100.9 for Canada as a whole, so local factors were apparently not responsible.?

Because the plant opened in 1948 and the study period ended in 1977 no follow up beyond 30 years from first exposure could be achieved. (It was expected when the study was planned that collated mortality data after 1977 for Canada would not be available.) Nevertheless, it is hoped that this population will continue to be followed up and the analysis repeated in several years.

We are grateful to all who helped with this research. In particular we thank Fiberglass, Canada, for financial support and for their continued involvement in this research endeavour; the Energy and Chemical Workers Union, Local 914, for their unremitting cooperation; members of the joint managementlabour steering committee; and pathologists, Drs Elliot McCaughey, Rene Lefebre, and Andrew Churg for reviewing tissue samples. We also thank Mrs Pat Yake for typing the many drafts of this report and for organising materials and meetings throughout the project and Ms Sandy Martin for her valuable help in the early stages of this project.

\section{References}

1 Stanton MF, Wrench C. Mechanisms of mesothelioma introduction with asbestos and fibrous glass. J Natl Cancer Inst 1969;48:236-44.

${ }^{2}$ Davis JMG. The fibrogenic effect of mineral dust injected into the pleural cavity of mice. Br J Exp Pathol 1972;53:190-201:

${ }^{3}$ Hill JW, Whitehead WS, Cameron JD, Hedgecock GA. Glass fibres: absence of pulmonary hazard in production workers. $\mathrm{Br}$ J Ind Med 1973;30:174-9.

4 Gross P, Tuma J, DeTreville RTP. Lungs of workers exposed to fibre glass: a study of their pathologic changes and their dust content. Arch Environ Health 1971;23:67-76.

${ }^{5}$ Bayliss DL, Dement JM, Wagoner JK, Blejer HP. Mortality patterns among fibrous glass production workers. Ann NY Acad Sci 1976;271:324-35.

- Case RAM, Lea AJ. Mustard gas poisoning, chronic bronchitis and lung cancer. Br J Prev Soc Med 1955;9:62-72.

${ }^{7}$ National Health and Welfare. Mortality atlas of Canada. Vol 2. General mortality. Ottawa: NHW, 1980:1-123. 